\title{
Joint Estimation of the Characteristics and Intensity of Poverty in Spain: The Case of Imputed Rent
}

\author{
José L. Calvo, ${ }^{1}$ Cristina Sánchez, ${ }^{2}$ and Pedro Cortiñas ${ }^{2}$ \\ ${ }^{1}$ Department of Economic Analysis I, UNED, 28040 Madrid, Spain \\ ${ }^{2}$ Department of Applied Economics and Statistics, UNED, 28040 Madrid, Spain \\ Correspondence should be addressed to Cristina Sánchez, csanchez@cee.uned.es
}

Received 12 July 2010; Accepted 28 September 2010

Academic Editor: Russell Smyth

Copyright (C) 2010 José L. Calvo et al. This is an open access article distributed under the Creative Commons Attribution License, which permits unrestricted use, distribution, and reproduction in any medium, provided the original work is properly cited.

\begin{abstract}
In 2007 the Spanish National Institute of Statistics modified the methodological approach to the Survey of Income and Living Conditions and included an estimate of Imputed Rent. It removes one of the main criticisms of Spanish poverty studies since this variable is associated with home ownership, and because more than $80 \%$ of Spanish families are homeowners, its exclusion biased the estimates of the size of Spain's poor population and poverty intensity. We estimate a Heckman model with a selection equation in which the dependent variable is the probability of being poor, and a truncated regression to explain poverty intensity. Our findings have at least two economic policy implications: Spanish social policy against poverty should take into account geographical differences but, at the same time, should consider Imputed Rent. Without this variable efforts should concentrate in Spanish less developed regions and rural areas, but if we include it poverty increases in urban population. The article has also reveals that most retired people cannot be considered poor if we take into account wealth (imputed rent included) instead of current income (pension).
\end{abstract}

\section{Introduction}

Poverty has always been an important area of study in Spanish Economic Science. From Plan [1] to Calvo and Sánchez [2], many authors have analyzed family income to assess the number and characteristics of poor people in Spain. Very different results emerge, as summarized in Table 7.

The main criticism of Spanish poverty studies stems from the calculation of household income. Until 2007, the Spanish Statistics on Income and Living Conditions (SILC) did not include an estimate of Imputed Rent (IMRENT) (INE [3]). This variable is associated with home ownership, and because more than $80 \%$ of Spanish families are homeowners, its exclusion biases the results. (Sánchez [4] obtains that without taking into account IMRENT $60 \%$ of Spanish poor are house owners with their house already paid. Their relative contribution to poverty reaches 1.9 (reference value $=1$ )) . In fact, Calvo and Sánchez [2] show that the characteristics of Spain's poor population change dramatically depending on whether Imputed Rent is considered. (In this paper we conduct a descriptive analysis comparing the situation of different household's classifications depending on the inclusion or not of IMRENT. At the same time we estimate a probit model to calculate the probability of leaving poverty when the variable is considered. The results show the relevance of this proxy to households' wealth since its incorporation changes the profile of Spanish poor: if we do not consider it, most people older than 65 are under the poverty line, especially women. But if we include it, a big share of widows and retired people rise above the poverty line. We also obtain a positive effect of being a home owner or paying a mortgage).

The Spanish National Institute of Statistics (INE) modified the methodological approach to SILC in 2007 and included, for the first time, an estimate of Imputed Rent. This made it possible to compare the characteristics of the Spanish poor using the traditional methodology, (without this variable), with a new approach (incorporating it).

As Amartya Sen [5] points out, there are at least, two different problems in poverty measurement: firstly we need to identify the share of the population that could be classified 
TABLE 1: Main features of poverty in Spain.

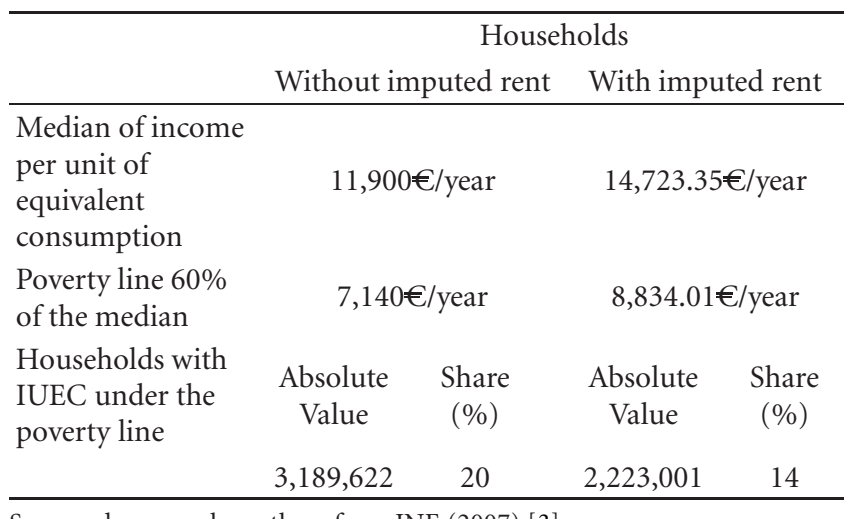

Source: drawn up by authors from INE (2007) [3].

as poor. That requires us to define a criterion, usually the poverty line, to separate poor people from the rest of the population. Secondly, we need to analyze the situation of people who fall under that threshold.

The methodology we follow in this article considers these two strategies. In doing so, we select the family, or more accurately, the household as the analysis unit. Secondly, we work with a poverty line obtained from an economic variable, the income per unit of equivalent consumption (IUEC), using European criteria. To work out IUEC we employ modified OECD equivalence scales and we establish the poverty line as $60 \%$ of IUEC median. Additionally, income is calculated in two ways: with and without Imputed Rent. Thirdly, we analyze the characteristics and situation of people under the poverty line.

To jointly study the determinants of being under the poverty line and the characteristics of the poor, we estimate a Heckman model that includes two equations. In the first equation - the selection equation-we test the variables that explain if a family can be considered poor or not. The second equation is the truncated regression where the explained variable is the distance from the household's IUEC to the poverty line with family variables defining the characteristics of the poor population and poverty intensity.

The article is structured as follows: Section 2 describes the data we have employed and the methodology applied to calculate the household income per unit of equivalent consumption. Section 3 establishes the main characteristics of Spanish poor and calculates some poverty indexes for Autonomous Communities. Section 4 discusses the model. Section 5 estimates a Heckman model for both cases, with and without IMRENT and comments on the results. The final sections offer the conclusions and a discussion about some social policy implications.

\section{Data}

2.1. The Living Conditions Survey. Database comes from the Living Conditions Survey (LCS) conducted by the Spanish Statistics National Institute (INE) (http://www.ine.es/daco/ daco42/condivi/ecv_metodo.pdf). This survey is included in a European project-the European Union Statistics on
TABLE 2: Change in the number of households in poverty changes due to the inclusion of IMRENT.

\begin{tabular}{lccc}
\hline & & \multicolumn{2}{c}{ With IMRENT } \\
& & Poor & No poor \\
\hline \multirow{2}{*}{ Without } & Poor & $2,036,696$ & $1,152,926$ \\
IMRENT & & $(12.8 \%)$ & $(7.2 \%)$ \\
& \multirow{2}{*}{ No poor } & 186,304 & $12,597,519$ \\
& & $(1.2 \%)$ & $(78.9 \%)$ \\
\hline Source: & &
\end{tabular}

Source: drawn up by authors from INE (2007) [3].

Income and Living Conditions (EU-SILC). Its main goal is to provide a reference source on comparative statistics on the distribution of income and social exclusion in the European environment.

EU-SILC is a systematic production of Community statistics on income and living conditions that include transversal and longitudinal data that are comparable and updated on income, the level and composition of poverty and social exclusion, on a national and European level. There is no obligation of using a specific model, but the response must provide certain transversal and longitudinal information using the instruments each Member State considers appropriate.

Although the data refer to both the transversal and longitudinal dimension, priority is granted to the production of high-quality transversal data as regards punctuality and comparability. The longitudinal component allows the survey to follow the same persons over a period of time, studying the changes produced in their lives when the conditions and socioeconomic policies are modified, and how they react to these changes. Since the efficiency of the political measures is very influenced by the manner in which the interested parties react to them, the SILC will provide extremely relevant information on the effects of the socioeconomic policies in the framework of the Single Market.

The LCS is a "Rotating Panel" survey. That is to say, since it is a panel it investigates the same units over the years. In the LCS, the panel units are only investigated for four years. The sample is composed by 4 panel subsamples. Therefore, every year, one is replaced by a new subsample. Each of the subsamples will remain in the survey for four years, after this period it is replaced by another subsample.

The survey uses the census definition given for a family dwelling, considering the census section as the primary census section sample and the main family dwelling as the last sample unit. Initially, the selected sample includes all private households resident in the main family dwellings selected.

After selecting a target population, and considering that persons live in dwellings composing private or group households (or reside in institutions), monitoring is performed via households, since as well as there being information on them for their location, they will also be considered study units, as the survey does not only study the behaviour of the individuals specifically, but also the behaviour of the households as a whole. 
TABLE 3: Spanish poverty intensity depending on the inclusion or not of IMRENT.

\begin{tabular}{|c|c|c|c|}
\hline$\%$ of the median & IUEC (€per year) & Number & Share of spanish poor \\
\hline \multicolumn{4}{|c|}{ Without IMRENT } \\
\hline Social precariousness (45-60\%) & 5,355 to 7,140 & $1,795,495$ & 56.3 \\
\hline Moderate poverty (30-44\%) & 3,570 to $5,354.90$ & 905,345 & 28.4 \\
\hline Severe poverty $(29-15 \%)$ & 1,785 to $3,569.90$ & 349,966 & 11.0 \\
\hline Extreme poverty (Less than 15\%) & Less than 1,785 & 138,816 & 4.3 \\
\hline \multicolumn{4}{|c|}{ With IMRENT } \\
\hline Social precariousness (45-60\%) & $6,625.51$ to 8,834 & $1,421,313$ & 63.9 \\
\hline Moderate poverty (30-44\%) & $4,417.00$ to $6,625.50$ & 569,552 & 25.6 \\
\hline Severe poverty $(29-15 \%)$ & $2,208.50$ to $4,416.90$ & 185,127 & 8.3 \\
\hline Extreme poverty (Less than 15\%) & Less than 2,208.50 & 47,008 & 2.1 \\
\hline
\end{tabular}

Source: drawn up by the authors.

In order to select each subsample of the LCS, a twostage design is used with first stage unit stratification. The first stage is formed by census sections and the second stage by main family dwellings. Within these no subsampling is carried out, investigating all dwellings that are their usual residence.

The framework used for the sample selection is an area framework formed by the relation of existing census sections used in the 2003 Municipal Register of Inhabitants. Second stage units use the list of main family dwellings in each of the sections selected for the sample.

The first stage units are grouped into strata in agreement with the size of the municipality to which the section belongs.

The following strata are considered.

(i) Stratum 0: Municipalities with more than 500.000 inhabitants.

(ii) Stratum 1: Province capital municipality (except the previous ones).

(iii) Stratum 2: Municipalities with more than 100,000 inhabitants (except the previous ones).

(iv) Stratum 3: Municipalities from 50,000 to 100,000 inhabitants (except the previous ones).

(v) Stratum 4: Municipalities from 20,000 to 50,000 inhabitants (except the previous ones).

(vi) Stratum 5: Municipalities with 10,000 to 20,000 inhabitants.

(vii) Stratum 6: Municipalities with less than 10,000 inhabitants.

For each Autonomous Community, an independent sample that represents it is designed, due to one of the objectives of the survey being to facilitate data. In order to achieve the goals set out for the survey to provide estimates with an acceptable level of reliability on a national and Autonomous Community level, the sample selected includes 16,000 dwellings distributed in 2,000 census sections. The sample is distributed between Autonomous Communities assigning a portion uniformly and another in proportion to the size of the Community. The uniform part corresponds to approximately $40 \%$ of the sections.
2.2. The Calculation of Poverty Line. We employed data from the LCS in 2007 (observations from 2006). It has a sample of 12,329 observations representing 16,116,202 Spanish households. (We dropped households with negative or zero income).

The most important methodological change INE introduced in the 2007 LCS was to take into account Imputed Rent. This variable refers to the value that would be attributed to any household that did not declare it paid a complete rent, whether the family is occupant-owner, lives in a house rented at a price lower than market price, or occupies the house free of charge. This Imputed Rent is only calculated for homes-and other associated places such as garages—used as the main residence.

The value attributed is obtained from the market rental paid for a similar home, taking into account several points: if the home is rented below market price, then the rent actually paid is subtracted. If the tenant receives any Administration or economic aid, it is subtracted. If the family is the owner, we deduct any Administration or economic aid as well as maintenance or renovation expenditures. As for the market rental, it is the amount that should be paid for an unfurnished home in the private market without including home expenses.

Imputed Rent adds to other revenues to obtain total family's income. (In Calvo et al. [6] total household income as well as income per unit of equivalent consumption without Imputed Income are worked out. Sánchez [4] calculates personal income with and without IMRENT.) In order to calculate the income per unit of equivalent consumption, we divide total family's income by the number of members of the household using modified OECD equivalence scales. Its formula is

$$
e_{h}=1+0,7\left(a_{h}-1\right)+0,5 m_{h},
$$

where $e_{h}$ is the equivalent scale, $a_{h}$ the number of adults in household $h$, and $m_{h}$ the number of children under 16 years.

We define the poverty line following EUROSTAT criterion as $60 \%$ of the median of IUEC. Therefore, those families whose income per unit of equivalent consumption is under the $60 \%$ of the distributional median are classified as poor households. 
TABle 4: Poverty indexes by autonomous community (I).

\begin{tabular}{|c|c|c|c|c|c|c|c|c|c|c|}
\hline \multirow{2}{*}{$\left({ }^{*}\right)$} & \multicolumn{5}{|c|}{ Without IMRENT } & \multicolumn{5}{|c|}{ With IMRENT } \\
\hline & $\mathrm{H}$ & I & $\mathrm{H}^{*} \mathrm{I}$ & CPI & CRI & $\mathrm{H}$ & I & $\mathrm{H}^{*} \mathrm{I}$ & CPI & CRI \\
\hline Andalucía & 0,285 & 0,274 & 0,078 & 16,77 & 1,004 & 0,198 & 0,225 & 0,045 & 16,39 & 0,981 \\
\hline Aragón & 0,148 & 0,266 & 0,039 & 2,88 & 0,973 & 0,103 & 0,231 & 0,024 & 2,97 & 1,007 \\
\hline Asturias & 0,154 & 0,234 & 0,036 & 2,18 & 0,858 & 0,111 & 0,190 & 0,021 & 2,11 & 0,828 \\
\hline Canary Islands & 0,272 & 0,305 & 0,083 & 4,82 & 1,118 & 0,229 & 0,219 & 0,050 & 4,12 & 0,955 \\
\hline Castilla-La Mancha & 0,323 & 0,258 & 0,084 & 3,96 & 0,946 & 0,236 & 0,210 & 0,050 & 3,84 & 0,918 \\
\hline Castilla and León & 0,255 & 0,282 & 0,072 & 6,09 & 1,032 & 0,178 & 0,239 & 0,043 & 6,17 & 1,044 \\
\hline Catalonia & 0,134 & 0,266 & 0,036 & 15,99 & 0,974 & 0,095 & 0,238 & 0,023 & 17,08 & 1,040 \\
\hline C.A. Ceuta and Melilla & 0,251 & 0,410 & 0,103 & 0,40 & 1,502 & 0,237 & 0,344 & 0,081 & 0,39 & 1,501 \\
\hline Madrid & 0,120 & 0,266 & 0,032 & 13,14 & 0,973 & 0,067 & 0,281 & 0,019 & 16,56 & 1,226 \\
\hline C. Valenciana & 0,178 & 0,264 & 0,047 & 10,77 & 0,965 & 0,118 & 0,197 & 0,023 & 9,57 & 0,858 \\
\hline Extremadura & 0,403 & 0,280 & 0,113 & 2,42 & 1,026 & 0,362 & 0,224 & 0,081 & 2,31 & 0,978 \\
\hline Galicia & 0,224 & 0,283 & 0,063 & 6,24 & 1,036 & 0,153 & 0,241 & 0,037 & 6,33 & 1,052 \\
\hline Balearic Islands & 0,159 & 0,277 & 0,044 & 2,46 & 1,015 & 0,096 & 0,254 & 0,024 & 2,69 & 1,107 \\
\hline La Rioja & 0,190 & 0,257 & 0,049 & 0,68 & 0,941 & 0,154 & 0,184 & 0,028 & 0,58 & 0,803 \\
\hline Navarre & 0,076 & 0,183 & 0,014 & 0,93 & 0,670 & 0,049 & 0,175 & 0,009 & 1,06 & 0,764 \\
\hline Basque Country & 0,127 & 0,288 & 0,037 & 5,26 & 1,056 & 0,077 & 0,217 & 0,017 & 4,72 & 0,948 \\
\hline Murcia & 0,259 & 0,284 & 0,074 & 3,01 & 1,040 & 0,165 & 0,277 & 0,046 & 3,50 & 1,209 \\
\hline TOTAL & 0,200 & 0,273 & 0,055 & 100,00 & 1,000 & 0,139 & 0,229 & 0,032 & 100,00 & 1,000 \\
\hline
\end{tabular}

Source: drawn up by authors from LCS (2007).

TABle 5: Poverty indexes by autonomous community (II).

\begin{tabular}{|c|c|c|c|c|c|c|c|c|c|c|}
\hline \multirow{2}{*}{$\left({ }^{*}\right)$} & \multicolumn{5}{|c|}{ Without IMRENT } & \multicolumn{5}{|c|}{ With IMRENT } \\
\hline & G & S & FGT3 & FGT4 & HAG & G & S & FGT3 & FGT4 & HAG \\
\hline Andalucía & 0,172 & 0,114 & 0,035 & 0,020 & 0,013 & 0,127 & 0,064 & 0,016 & 0,008 & 0,006 \\
\hline Aragón & 0,189 & 0,060 & 0,018 & 0,011 & 0,007 & 0,118 & 0,033 & 0,009 & 0,004 & 0,003 \\
\hline Asturias & 0,141 & 0,053 & 0,014 & 0,007 & 0,005 & 0,126 & 0,032 & 0,007 & 0,004 & 0,003 \\
\hline Canary Islands & 0,177 & 0,116 & 0,038 & 0,022 & 0,015 & 0,131 & 0,074 & 0,020 & 0,011 & 0,009 \\
\hline Cantabria & 0,137 & 0,049 & 0,012 & 0,006 & 0,005 & 0,164 & 0,029 & 0,006 & 0,003 & 0,002 \\
\hline Castilla-La Mancha & 0,140 & 0,117 & 0,032 & 0,015 & 0,012 & 0,116 & 0,071 & 0,017 & 0,007 & 0,007 \\
\hline Castilla and León & 0,179 & 0,105 & 0,034 & 0,021 & 0,012 & 0,139 & 0,061 & 0,018 & 0,010 & 0,007 \\
\hline Catalonia & 0,160 & 0,051 & 0,016 & 0,009 & 0,006 & 0,158 & 0,034 & 0,010 & 0,005 & 0,003 \\
\hline C.A. Ceuta and Melilla & 0,269 & 0,143 & 0,059 & 0,039 & 0,020 & 0,223 & 0,116 & 0,045 & 0,029 & 0,014 \\
\hline Madrid & 0,166 & 0,046 & 0,015 & 0,008 & 0,005 & 0,184 & 0,027 & 0,009 & 0,005 & 0,003 \\
\hline C. Valenciana & 0,169 & 0,069 & 0,022 & 0,013 & 0,008 & 0,125 & 0,035 & 0,008 & 0,004 & 0,003 \\
\hline Extremadura & 0,145 & 0,155 & 0,047 & 0,025 & 0,018 & 0,126 & 0,117 & 0,030 & 0,014 & 0,011 \\
\hline Galicia & 0,170 & 0,091 & 0,029 & 0,016 & 0,010 & 0,142 & 0,053 & 0,015 & 0,007 & 0,005 \\
\hline Balearic Islands & 0,186 & 0,065 & 0,022 & 0,014 & 0,008 & 0,113 & 0,032 & 0,009 & 0,005 & 0,004 \\
\hline La Rioja & 0,151 & 0,070 & 0,020 & 0,011 & 0,008 & 0,123 & 0,044 & 0,010 & 0,005 & 0,004 \\
\hline Navarre & 0,134 & 0,022 & 0,006 & 0,004 & 0,003 & 0,112 & 0,013 & 0,003 & 0,002 & 0,001 \\
\hline Basque Country & 0,213 & 0,056 & 0,019 & 0,012 & 0,007 & 0,129 & 0,025 & 0,006 & 0,003 & 0,002 \\
\hline Murcia & 0,178 & 0,107 & 0,035 & 0,021 & 0,013 & 0,150 & 0,064 & 0,020 & 0,012 & 0,007 \\
\hline TOTAL & 0,172 & 0,079 & 0,025 & 0,014 & 0,009 & 0,140 & 0,047 & 0,013 & 0,006 & 0,005 \\
\hline
\end{tabular}

Source: drawn up by authors from LCS (2007). 


\section{Poverty in Spain}

3.1. Main Characteristics. The median of Spanish households' IUEC in 2007 was 11,900€ per year without Imputed Rent and 14,723.35€ per year if we include Imputed Rent. This means that the poverty line is established in $7,140 €$ without IMRENT, but at $8,834.01 €$ with IMRENT included. The results for the Spanish population are summarized in Table 1.

As we can see in Table 1, incorporation of IMRENT leads to a reduction in the size of the Spanish poor population. If we do not consider this variable, the share of poor households rises to $20 \%$, with more than 3 million families under the poverty line. If we include Imputed Rent, the proportion of the households living in poverty drops to $14 \%$ and the total number of households with IUEC smaller than $60 \%$ of the median decreases by almost one million.

In fact, incorporation of IMRENT creates changes in two directions: some households move from being poor when we do not consider this variable to being over the poverty line when we include it, and visa versa. Table 2 summarizes those changes.

More than one million Spanish households $(1,152,926)$ rise above the poverty line when we include IMRENT in their Income per Unit of Equivalent Consumption, and only 186,304 drop below the poverty line. The incorporation of imputed rent significantly changes one's estimate of the size of Spain's poor population.

The other question related to the measurement of poverty we mentioned in the Introduction is the situation of people under the poverty line. Because that threshold changes when we introduce IMRENT, as we have seen in Tables 1 and 2, it is logical that the characteristics of Spanish poor households also change. Table 3 classifies the poor into four groups depending on poverty intensity: those close to poverty line-between $45 \%$ and $60 \%$ of the median-are the social precariousness, moderate poverty contains Spanish poor households with an Income per Unit of Equivalent Consumption between $44 \%$ and $30 \%$, severe poverty includes those households with IUEC between 29 and 15\%, and extreme poverty take into account of those with less than $15 \%$.

As we see in Table 3, the inclusion of IMRENT not only reduces the number of Spanish poor, but also changes the distribution of that population. The share of people in extreme poverty decreases by more than two percentage points from $4.3 \%$ to $2.1 \%$ and the population close to the poverty line increases from $56.3 \%$ to $63.9 \%$. These two results are very relevant: more than one-half of Spain's poor are very close to the "threshold" of overcoming poverty with a relative small effort. On the other side, the introduction of IMRENT reduces to 47,000 the number of households that are far away from the poverty line.

3.2. Poverty Indexes by Autonomous Communities. We have thought that it should be interesting to briefly analyze the very heterogeneous situation of Spanish poverty depending on the Spanish Autonomous Community the household sited, since location will be a relevant variable in the estimation of next sections. Therefore, we have calculated the following indexes.

(1) Head count ratio $(H)$ : defined as the share of poor people ( $q$, number of people under poverty line) in the population $(n)$.

$$
H=\frac{q}{n}
$$

This is the principal measure used in poverty studies because of its simplicity. Nevertheless, it is not sensitive to the degree of poverty. In fact, it is independent of the poor distribution

(2) Income gap ratio (I), calculated as

$$
I=\frac{\sum_{i=1}^{q}\left(z-y_{i}\right)}{q z}=1-\frac{\mu_{p}}{z},
$$

where $z$ is poverty line, $y_{1} \ldots y_{q}$ are households incomes per unit of equivalent consumption under the poverty line, and $\mu_{p}$ is the mean of those incomes. This index complements $H$. It is not sensitive to the share poor people represent in total population, just the contrary of $H$.

(3) Poverty gap ratio $(H I)$ :

$$
\begin{aligned}
H I & =\frac{\sum_{i=1}^{q}\left(z-y_{i}\right)}{n z}=\frac{q}{n}-\left(\frac{\sum_{i=1}^{q} y_{i}}{n z}\right) \\
& =H\left(1-\frac{\sum_{i=1}^{q} y_{i}}{n z}\right)=H x I .
\end{aligned}
$$

Combination of $H$ and $I$, it takes into account at the same time the share of poor people in the population and the degree of poverty. It measures the necessary amount of income to position all the poor on poverty line, divided by the product of total population by the poverty line $(n z)$.

(4) Percentage Contribution to Poverty (CPI), measured as

$$
\mathrm{CPI}=\left(\frac{n_{i}}{N} \frac{I_{i}}{I}\right) \times 100,
$$

where now $N$ is Spanish population, $n_{i}$ are the inhabitants of the ith Spanish Autonomous Community, $I_{i}$ is the income gap ratio for the same Community, and $I$ is the Spanish income gap ratio.

(5) Relative Contribution to Poverty (CRI):

$$
\mathrm{CRI}=\left(\frac{I_{i}}{I}\right)
$$

with $I_{i}$ the income gap ratio in the ith Community and $I$ the 
Spanish income gap ratio. If CRI is bigger than 1 , then there is an overrepresentation of that CC.AA. in poor population, showing that the situation of that Community is worse than Spanish mean; on the contrary, if CRI is smaller than 1 , then the Community is underrepresented and it is better off than the mean.

(6) Sen index $(S)$ :

$$
S=H[I+(1-I) \quad G]
$$

a combination of Head Count Ratio $(H)$, Income Gap Ratio $(I)$, and Gini's coefficient $(G)$.

Sen [5] was looking for a poverty index observing three axioms: (a) it only depends on poor households' incomes, meaning that the income of nonpoor people and its changes do not affect the index; (b) it increases when the poor's income decreases; and (c) it is sensitive to changes in poor people's distribution. $H$ and $I$ satisfy the first axiom; $I$ satisfy the second one but not $H$; and neither $I$ nor $H$ satisfies the third. On the contrary, a measure of inequality, Gini's coefficient, satisfies all of them. Therefore, Sen Index includes information about the poor, poverty intensity, and a measure of inequality between poor households, since Gini's coefficient is worked out taking only into account people under poverty line.

(7) The family of Foster, Green and Thorbecke Indexes (FGT):

$$
\operatorname{FGT}_{\alpha}(y ; z)=\frac{1}{n} \sum_{i=1}^{q}\left(\frac{z-y_{i}}{z}\right)^{\alpha-1} \quad \alpha>0
$$

These indexes consider the relative importance of income distance to poverty line. They weight poverty deficits. Those weights depend on the household's income distance to poverty line. $\alpha$ is known as poverty aversion parameter and the bigger this parameter more relevance is attributed to poorest families.

If $\alpha=1$, the FGT index is identical to $H$;

If $\alpha=2$, it is $H I$;

If $\alpha=3$, the expression is

$$
\operatorname{FGT}_{\alpha=3}(y ; z)=\frac{1}{n} \sum_{i=1}^{q}\left(\frac{z-y_{i}}{z}\right)^{2}=H\left[I^{2}+(1-I)^{2} C V^{2}\right]
$$

with CV being the poor's variation coefficient.

Finally, if $\alpha=4$, the correspondent index is

$$
\operatorname{FGT}_{\alpha=4}(y ; z)=\frac{1}{n} \sum_{i=1}^{q}\left(\frac{z-y_{i}}{z}\right)^{3}
$$

It is employed when the researcher wants to emphasize the relevance of the poorest.
(8) Hagenaars index (HAG):

$$
\operatorname{HAG}(y, z)=\frac{q}{n}\left[\frac{\log z-\log \mu}{\log z}\right] .
$$

$\mu$ is the geometric mean of income per unit of equivalent consumption. This index considers information about the share of poor on total population along with an aggregated measure of poverty degree. The value of the index rises with poor people's income distance to poverty threshold (there is a positive relationship between index value and the distance).

The results are included in Tables 4 and 5.

\section{The Proposed Model}

As we have observed in previous sections, the introduction of IMRENT alters the estimated size of Spain's poor population and poverty intensity. This leads to two questions:

(i) what characteristics define Spanish poor households and do they change when we introduce IMRENT?

(ii) what households' features can explain the intensity of Spanish poverty? and again, do the features change with the inclusion of IMRENT?

In order to answer those questions and assess the determinants of being under the poverty line and poverty intensity, we propose a Heckman model. It jointly estimates two equations: a selection equation in which the dependent variable is the probability of being under the poverty linequestion one-and a truncated regression where explained variable is the distance from the household's IUEC to poverty line-question two. Explanatory variables are the household's characteristics.

The independent variables included in the study are the following: (A descriptive analysis of Spanish poor depending on IMRENT and household's characteristics can be found in Calvo and Sánchez [2].)

(i) Location characteristics. We incorporate a dummy variable for each Spanish Autonomous Community (17). We also include three dummy variables depending on the size of the town in which the household resides: densely, (Population density larger than 500 inhabitants per $\mathrm{Km}^{2}$ and total population bigger than 50.000 inhabitants.) medium ( Population density larger than 100 inhabitants per $\mathrm{Km}^{2}$ and total population smaller than 50.000 inhabitants. This is the reference group variable.), and sparsely populated areas.

(ii) Socioeconomic characteristics, including the following.

(a) Number of household members.

(b) Type of household. Here we introduce 9 dummy variables depending on household composition: a man living alone less than 30 years old, (The variable takes value 1 if the household is composed by a man living alone less than 30 
years old and 0 otherwise. The same definition applies to the rest of the variables. The reference group was households composed by a man or a woman 30 to 64 years old or two adults younger than 65 with no children.) a woman living alone less than 30 years old, a man or a woman living alone between 30 to 64 years old, a man living alone older than 65, a woman living alone older than 65 , an adult with at least a dependent child, two adults with no children, at least one of them older than 65 years, two adults without children younger than 64 , and two adults with dependent children.

(c) Household economic activity situation. We define four dummy variables: all members of the household nonworking, (We consider nonworking people those out of the labor market (retired, invalidity...). Therefore, this classification is different from unemployed.) all of them working, some working and some unemployed, (Control group.) and all household members unemployed.

(d) System of house tenancy. Four dummy variables: complete ownership, (It takes value 1 if the household owns the house and it is completely paid and 0 otherwise. On the contrary, mortgage dummy variable takes value 1 if the household owns the house but it has to pay a mortgage.) if the house owner is paying a mortgage, if the house is rented at a market price (Control group), and other types of rent. (It includes two cases: free of charge or with a rent smaller than the market price.)

The dependent variables, as we have said, are two: for the selection equation we include a dummy taking value 1 if the household is under poverty line and 0 otherwise, and for the truncated regression, the variable is the difference between household's IUEC and the poverty line (In the case of the estimation without IMRENT the calculus is VAR2 = 7, $140-$ IUEC $_{i}$ where $i$ denotes the household. For the other case, with IMRENT, the variable is calculated as VAR3 = $8,834-$ IUEC $_{i}$.).

\section{Estimation Results}

Table 6 summarizes the results for the estimates with and without IMRENT. We employ the same variables for both equations.

The first result we can observe in Table 6 is the interrelationship between the selection equation and the outcome equation given the Wald test rejection of the independence between of the two equations. Second, most of the signs on the coefficients are unaffected by the inclusion of IMRENT. The probability of being poor increases with the number of household members; for families living in Extremadura, Castilla and León, Castilla-La Mancha Andalucía, Canary Islands, Murcia and Ceuta and Melilla, or in a sparsely populated areas; for households with all its members unemployed or not working; for women younger than 30 living alone; for households with two adults with children or 1 adult and 1 child. On the other hand, the probability of being under the poverty line decreases for households in Cantabria, the Basque Country, Navarre, Madrid, Catalonia, Aragón, Balearic Islands, or Asturias; households in densely populated cities; households in which members have jobs; and for households with homeowners, with or without a mortgage.

In the truncated regression, the intensity of poverty (measured by the distance between the poverty line and household income per unit of equivalent consumption) increases with the number of household members; is higher for households in the Basque Country, Aragón, Balearic Islands, Castilla and León, Murcia, Ceuta and Melilla; higher for households with all its members unemployed; higher for men and women younger than 30 and for adults with children. On the other side, intensity of poverty is moderated for households in Asturias, Castilla-La Mancha, Andalucía, Canary Islands; households living in a densely or sparsely populated area; with all its members not working; with a woman older than 65, two adults one of them older than 65, or two adults with children and home ownership.

The introduction of IMRENT changes the signs of several variables. Households comprised of a man or a woman older than 65 living alone increases the probability of being under the poverty line if we do not take into account Imputed Rent, but decreases the probability of poverty if we include it. The same happens with the variable "other type of rented houses". In the case of poverty intensity the effect of some Autonomous Communities change their sign, moving from a negative effect to a positive one. This is the case with Navarre, Madrid, and Catalonia. The same pattern follows for the effects of belonging to a household with all its members employed and living alone and being more than 65 years old. The sign changes from positive to negative for households in Extremadura and for other types of rented houses.

\section{Conclusions}

The main criticism of Spanish poverty studies is the household income calculation. Until 2007, the Spanish Statistics on Income and Living Conditions did not include estimates of house property income (IMRENT) and because more than $80 \%$ of Spanish families are homeowners, its exclusion likely biases the results. In 2007, the Spanish National Institute of Statistics modified the methodological approach to the SILC and included an estimate of Imputed Rent.

As we have demonstrated, the introduction of IMRENT alters estimate of the size of Spain's poor population and poverty intensity. We have set out two questions related to the introduction of Imputed Rent: does the introduction or IMRENT change the characteristics that determine the probability of being poor? Does the introduction of IMRENT change the household attributes that explain the intensity of poverty in Spain? 
TABLE 6: Estimation results for Heckman's model.

\begin{tabular}{|c|c|c|c|}
\hline Variable & Without IMRENT & With IMRENT & Sign \\
\hline \multicolumn{4}{|c|}{ Selection equation } \\
\hline Number of members & $.0395(79.13)$ & $.1567(294.62)$ & $(+)$ \\
\hline Cantabria & $-.1850(48.82)$ & $-.2409(56.81)$ & $(-)$ \\
\hline Basque Country & $-.2554(120.74)$ & $-.2089(87.24)$ & $(-)$ \\
\hline Navarre & $-.6135(139.49)$ & $-.6333(125.83)$ & $(-)$ \\
\hline Madrid & $-.2631(169.94)$ & $-.4198(228.99)$ & $(-)$ \\
\hline Catalonia & $-.2224(159.27)$ & $-.2376(152.12)$ & $(-)$ \\
\hline Aragón & $-.2886(111.52)$ & $-.2576(90.66)$ & $(-)$ \\
\hline Asturias & $-.2415(89.42)$ & $-.1821(61.22)$ & $(-)$ \\
\hline Balearic Islands & $-.1768(64.57)$ & $-.3566(112.96)$ & $(-)$ \\
\hline Extremadura & $.4146(169.17)$ & $.4761(190.61)$ & $(+)$ \\
\hline Castilla and León & $.1034(58.90)$ & $.1149(60.32)$ & $(+)$ \\
\hline Castilla-La Mancha & $.3156(159.68)$ & $.2467(117.72)$ & $(+)$ \\
\hline Andalucía & $.2415(192.13)$ & $.1760(127.79)$ & $(+)$ \\
\hline Canary Islands & $.2800(143.58)$ & $.3042(147.75)$ & $(+)$ \\
\hline Murcia & $.1367(58.71)$ & $.0132(5.11)$ & $(+)$ \\
\hline Ceuta and Melilla & $.1325(18.34)$ & $.2371(31.36)$ & $(+)$ \\
\hline Densely populated & $-.0972(88.60)$ & $-.0581(47.18)$ & $(-)$ \\
\hline Sparsely populated & $.1609(140.37)$ & $.3288(262.58)$ & $(+)$ \\
\hline All nonworking & $.6381(343.51)$ & $.4714(236.83)$ & $(+)$ \\
\hline All working & $-.1082(72.86)$ & $-.1160(74.98)$ & $(-)$ \\
\hline All unemployed & $.9524(389.43)$ & $.8409(333.21)$ & $(+)$ \\
\hline Man younger than 30 & $-.2491(52.00)$ & $-.3051(56.06)$ & $(-)$ \\
\hline Man older than 65 & $.2749(100.19)$ & $-.3210(88.03)$ & $(+) /(-)$ \\
\hline Woman younger than 30 & $.7842(134.80)$ & $.6668(105.91)$ & $(+)$ \\
\hline Woman older than 65 & $.6364(344.16)$ & $-.1534(66.19)$ & $(+) /(-)$ \\
\hline 2 adults one of them older than 65 & $.0578(39.42)$ & $.1644(100.74)$ & $(+)$ \\
\hline 2 adults with children & $.3733(313.48)$ & $.3034(242.23)$ & $(+)$ \\
\hline 1 adult with 1 child & $.5217(177.81)$ & $.6217(204.75)$ & $(+)$ \\
\hline House ownership & $-.2327(155.05)$ & $-.9925(695.55)$ & $(-)$ \\
\hline House with mortgage & $-.5052(312.98)$ & $-1.2454(806.08)$ & $(-)$ \\
\hline Other type of rented house & $.0836(47.09)$ & $-.6043(347.93)$ & $(+) /(-)$ \\
\hline Constant & $-1.094(406.68)$ & $-.9215(334.82)$ & $(-)$ \\
\hline \multicolumn{4}{|c|}{ Truncated regression } \\
\hline Number of members & $78.62(71.95)$ & $146.18(109.82)$ & $(+)$ \\
\hline Cantabria & $-248.69(27.60)$ & - & $(-) /$ \\
\hline Basque Country & $133.06(25.46)$ & $398.96(55.64)$ & $(+)$ \\
\hline Navarre & $-501.97(41.78)$ & $99.20(6.26)$ & $(-) /(+)$ \\
\hline Madrid & $-49.01(13.02)$ & $653.82(124.04)$ & $(-) /(+)$ \\
\hline Catalonia & $-.37 .67(11.39)$ & $285.38(66.05)$ & $(-) /(+)$ \\
\hline Aragón & $135.60(22.13)$ & $436.24(54.88)$ & $(+)$ \\
\hline Asturias & $-185.33(29.12)$ & $-40.17(4.90)$ & $(+) /$ \\
\hline Balearic Islands & - & $347.56(38.62)$ & $(+)$ \\
\hline Extremadura & $49.64(10.33)$ & $-242.30(42.43)$ & $(+) /(-)$ \\
\hline Castilla and León & $160.36(42.65)$ & 340.25 (68.19) & $(+)$ \\
\hline Castilla-La Mancha & $-42.02(10.21)$ & $-157.18(30.15)$ & $(-)$ \\
\hline Andalucía & $-47.81(17.22)$ & $-52.82(14.76)$ & $(-)$ \\
\hline Canary Islands & $139.67(33.41)$ & $-232.03(45.42)$ & $(-)$ \\
\hline
\end{tabular}


Table 6: Continued.

\begin{tabular}{|c|c|c|c|}
\hline Variable & Without IMRENT & With IMRENT & Sign \\
\hline Murcia & $109.33(22.46)$ & $429.94(64.58)$ & $(+)$ \\
\hline Ceuta and Melilla & $724.58(48.74)$ & $585.40(34.01)$ & $(+)$ \\
\hline Densely populated & $-84.95(34.13)$ & $-122.72(36.47)$ & $(-)$ \\
\hline Sparsely populated & $-43.30(16.87)$ & $-144.08(42.46)$ & $(-)$ \\
\hline All nonworking & $-319.65(64.30)$ & $-288.04(55.97)$ & $(-)$ \\
\hline All working & $-214.82(60.31)$ & $30.94(7.64)$ & $(-) /(+)$ \\
\hline All unemployed & $325.87(54.72)$ & $145.41(24.77)$ & $(+)$ \\
\hline Man younger than 30 & $1373.67(106.76)$ & $1473.70(91.70)$ & $(+)$ \\
\hline Man older than 65 & $-827.46(153.48)$ & $92.70(8.89)$ & $(-) /(+)$ \\
\hline Woman younger than 30 & $1278.79(107.36)$ & $1197.24(79.77)$ & $(+)$ \\
\hline Woman older than 65 & $-762.28(176.80)$ & $-251.12(40.51)$ & $(-)$ \\
\hline 2 adults one of them older than 65 & $-339.96(106.59)$ & $-548.93(130.16)$ & $(-)$ \\
\hline 2 adults with children & $-286.29(89.77)$ & $-349.29(104.01)$ & $(-)$ \\
\hline 1 adult 1 child & $796.88(126.74)$ & $117.28(16.70)$ & $(+)$ \\
\hline House ownership & $-54.00(23.30)$ & $-229.57(80.61)$ & $(-)$ \\
\hline House with mortgage & - & - & \\
\hline Other type of rented house & $126.81(38.88)$ & $-22.01(6.23)$ & $(+) /(-)$ \\
\hline Constant & $2334.06(201.97)$ & $3298.26(360.24)$ & $(+)$ \\
\hline Wald test $\chi^{2}(29)$ & 333865.82 & 228470.60 & \\
\hline athrho & $-.0176(4.97)$ & $-5890(314.31)$ & \\
\hline lnsigma & $7.3121(18326.31)$ & $7.4878(9054.02)$ & \\
\hline Wald test of independent equations $($ rho $=0) \chi^{2}(1)=$ & 23.91 & 76741.79 & \\
\hline
\end{tabular}

T-ratios within parenthesis. All the estimates are significant at $99 \%$.

In order to answer those questions we proposed a Heckman model. It jointly estimates two equations: a selection equation in which the dependent variable is the probability of being under the poverty line, and a truncated regression where the explained variable is the distance from household's IUEC to poverty line.

The results show that the Heckman model is a good approach because both equations are interrelated. At the same time, we also observe that some characteristics change when we introduce IMRENT, especially those related to Autonomous Communities and the size of the community in which the household is located. But perhaps one of the most important differences is related to age: if we do not consider Imputed Rent, the probability of being under the poverty line increases with age, and most retired people and widows-those being more than 65 years old-can be classified as poor. On the other hand, if we do we take IMRENT into account, living alone and being elderly decrease the probability of being poor.

\section{Policy Implications of the Study}

Our findings have at least two economic policy implications: one is related to location heterogeneity and the second one concerns aged people.

Spanish social policy against poverty should take into account geographical differences but, at the same time, should consider imputed rent. Without this last variable, efforts should concentrate in Spanish less developed regions and rural areas. But if we include it, poverty increases in urban population. Therefore, new poverty studies should be developed taking into consideration regional heterogeneity and imputed rent in order to define poverty fight policy.

The paper has also revealed that most retired people cannot be considered poor if we take into account wealth (imputed rent included) instead of current income (pension). This has some implications in social policy.

Spain is confronting the challenges associated with financing its Public Pensions' System since its situation is not sustainable in the future. Spanish pensions' system is contributive, so people who are working today pay the pensions of retirees with their contributions to the Social Security System. At the same time, social policy applied for successive governments has supported the idea of guaranteeing retired people living conditions with their pensions.

This system works when occupied people are more than retired ones. But with an unemployment rate of 20 percent and more than 8 million retirees, the situation is unbearable. It is not possible to finance too many people living too longmost people live more than 20 years after retirement age-in the actual crisis and in the future.

The article proposes a line of study: taking into account not only current income but wealth (Imputed Rent) when assessing the adequacy of retirement pensions. This policy 


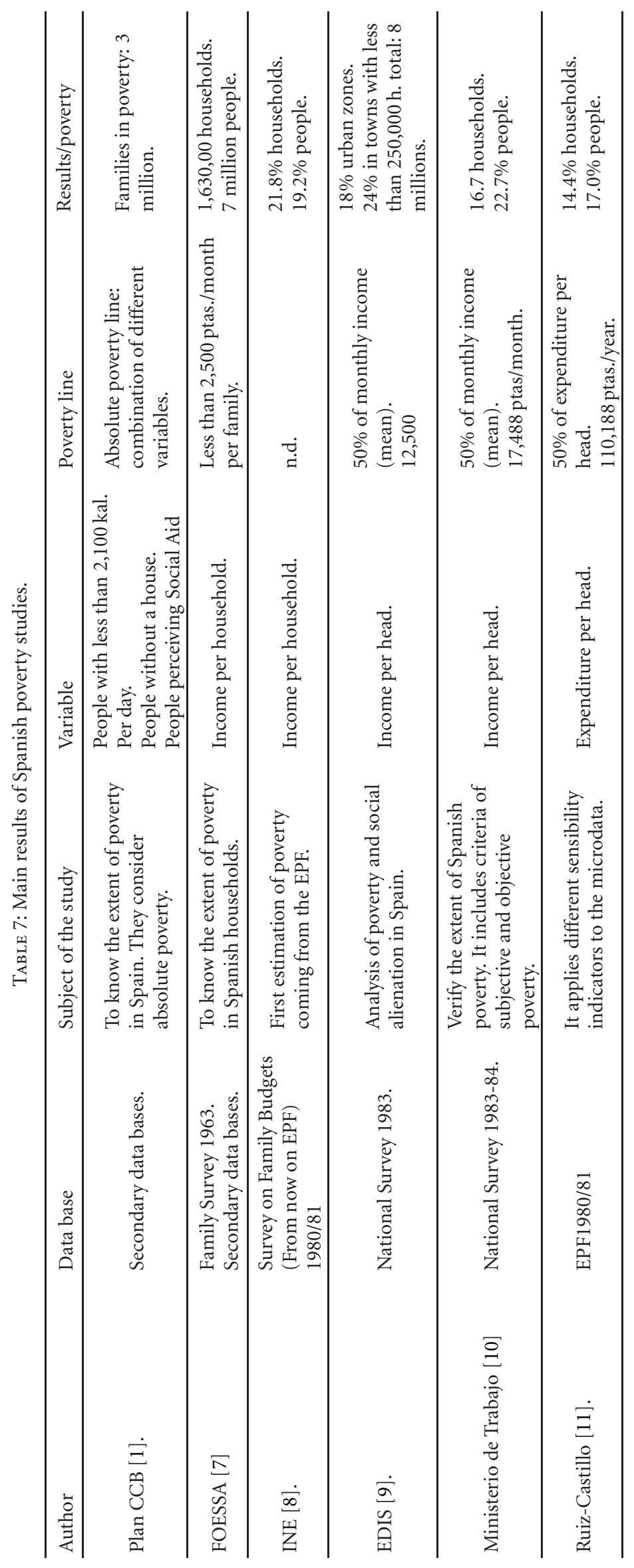




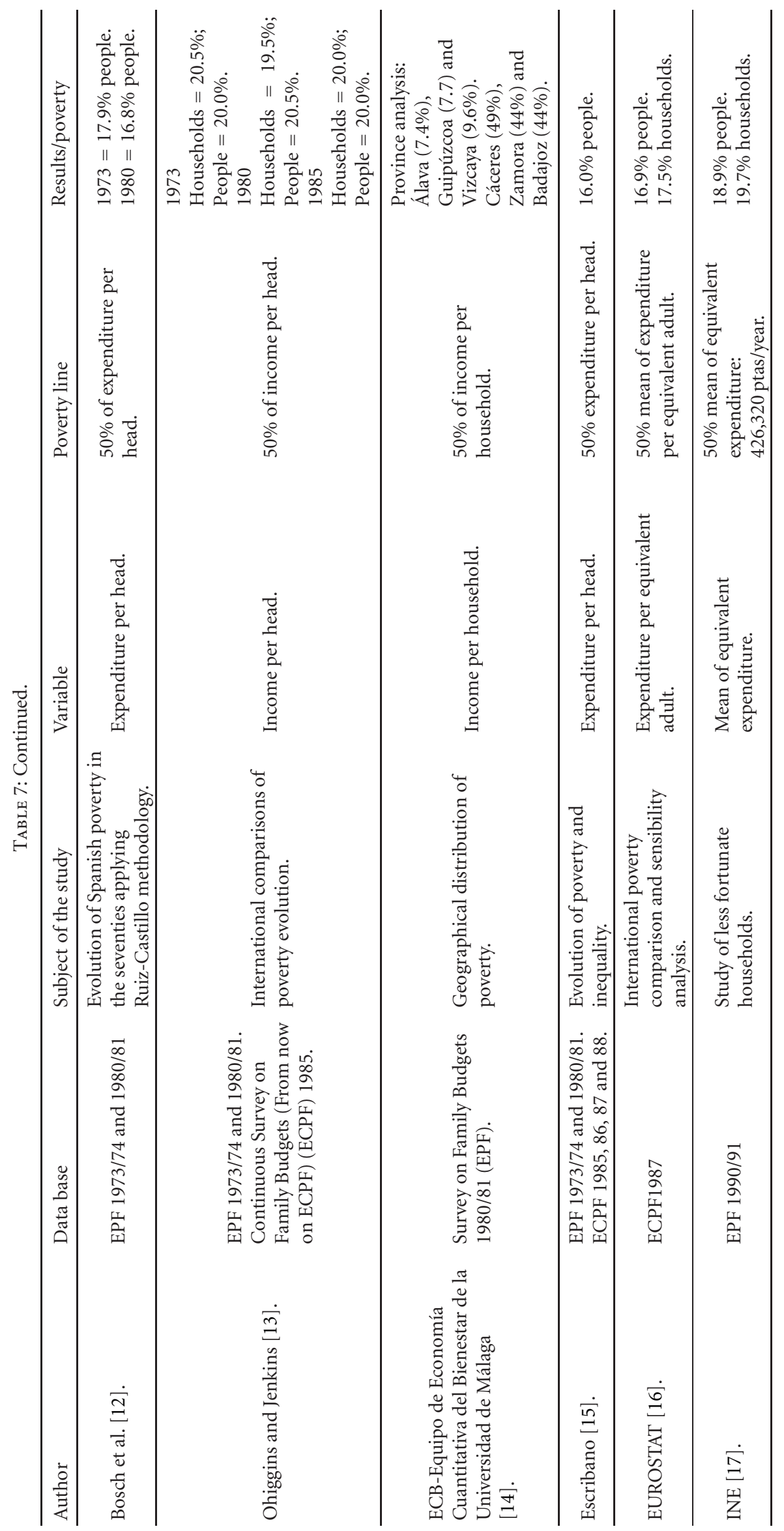




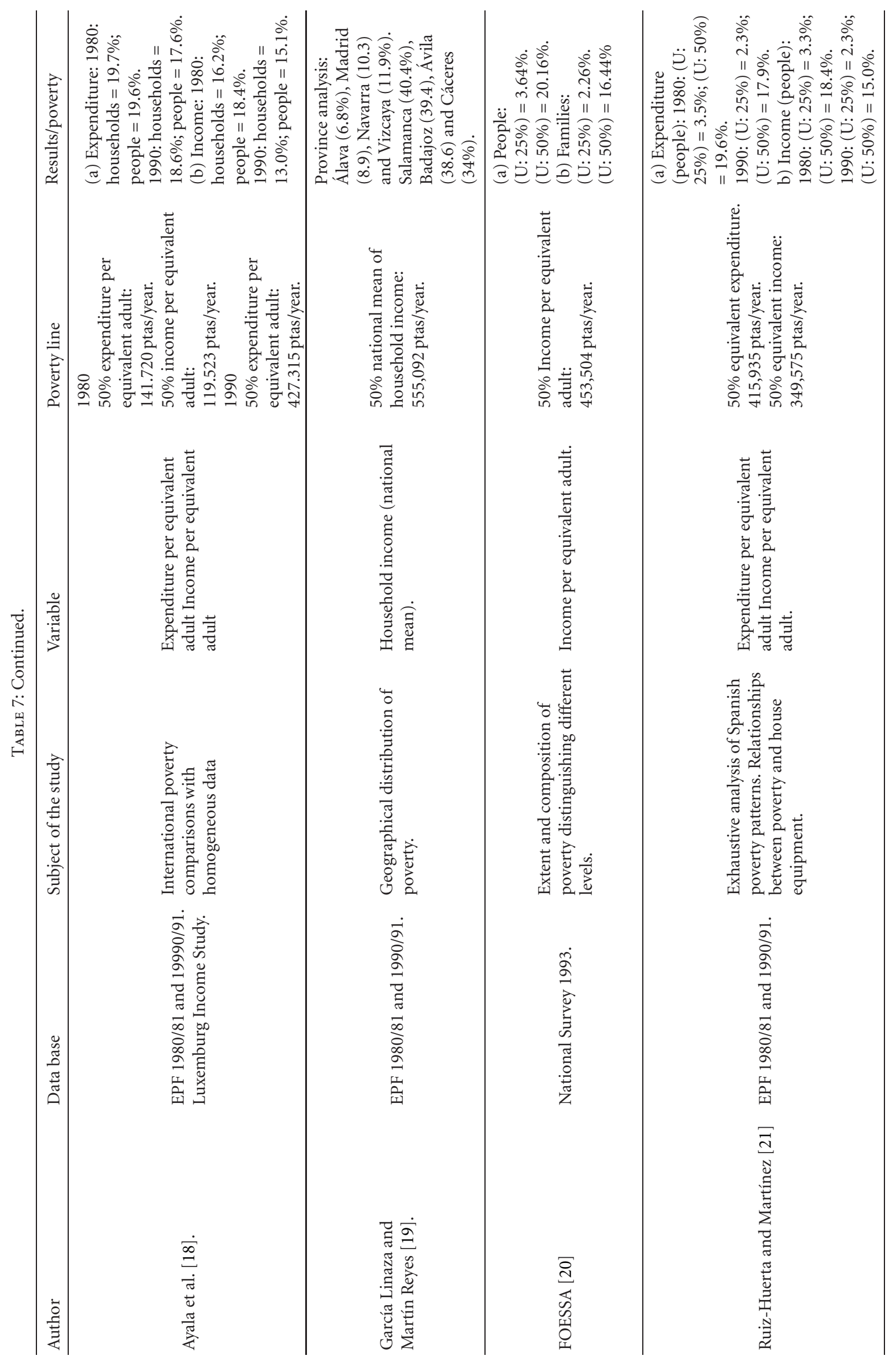




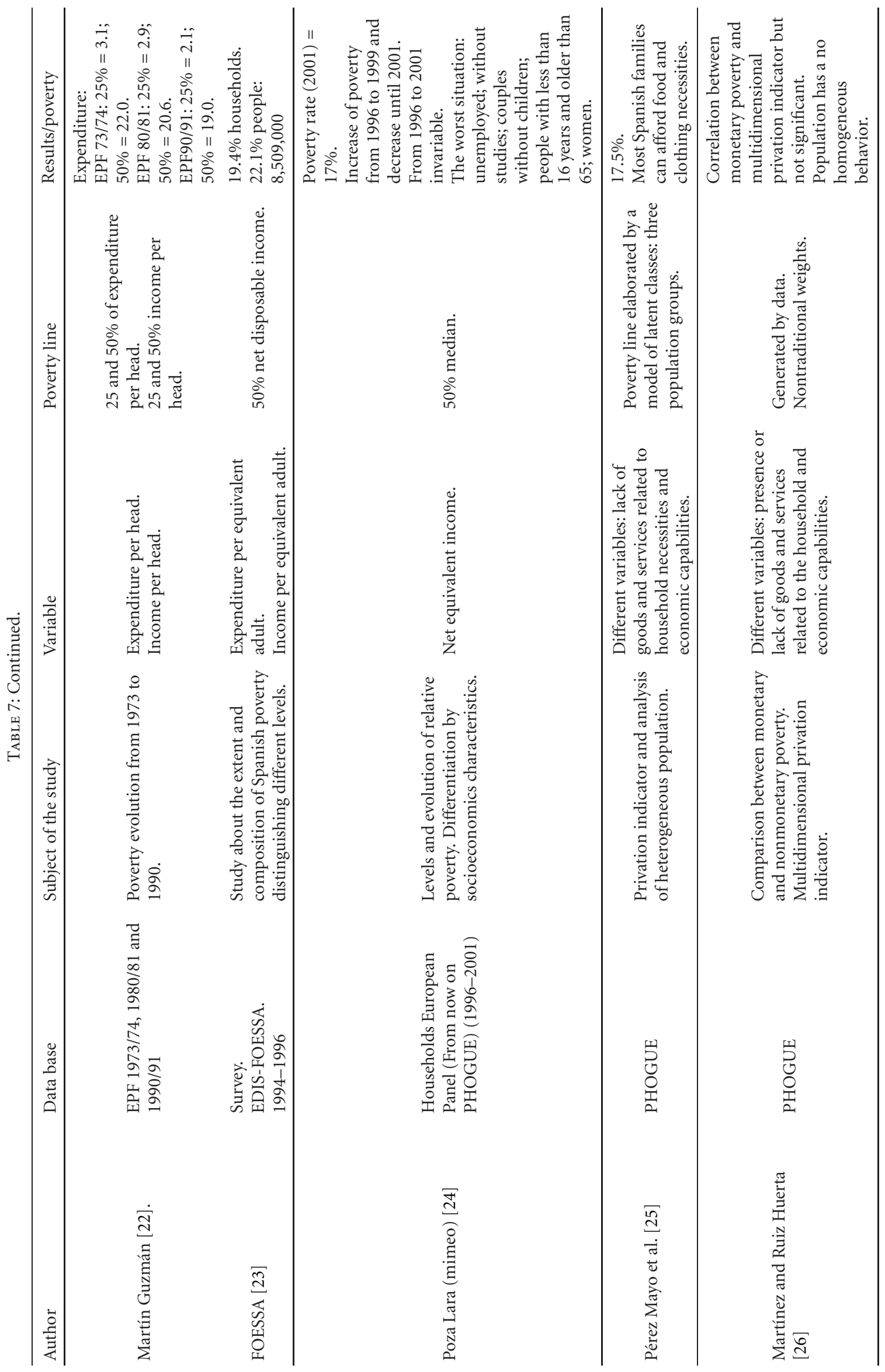




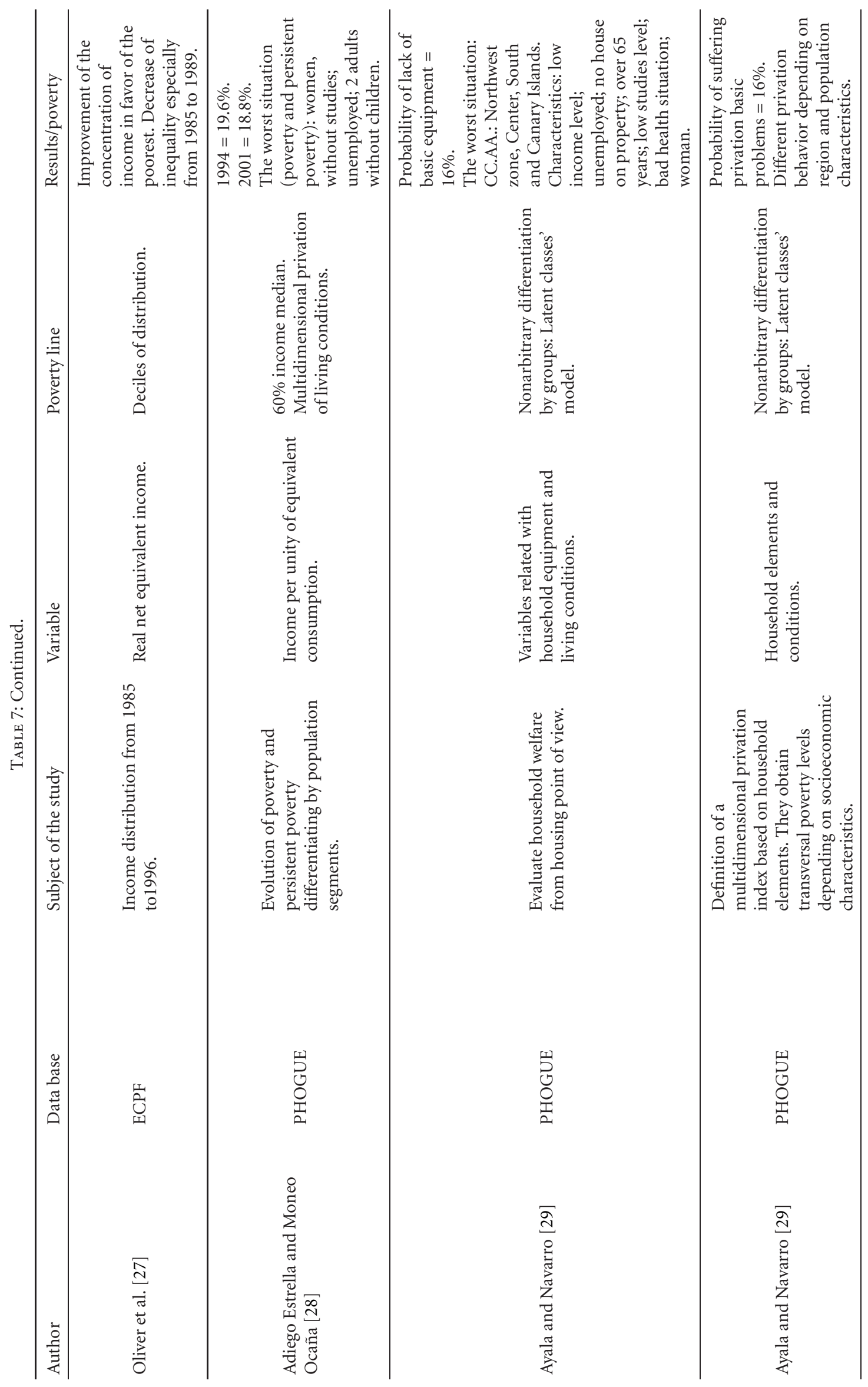




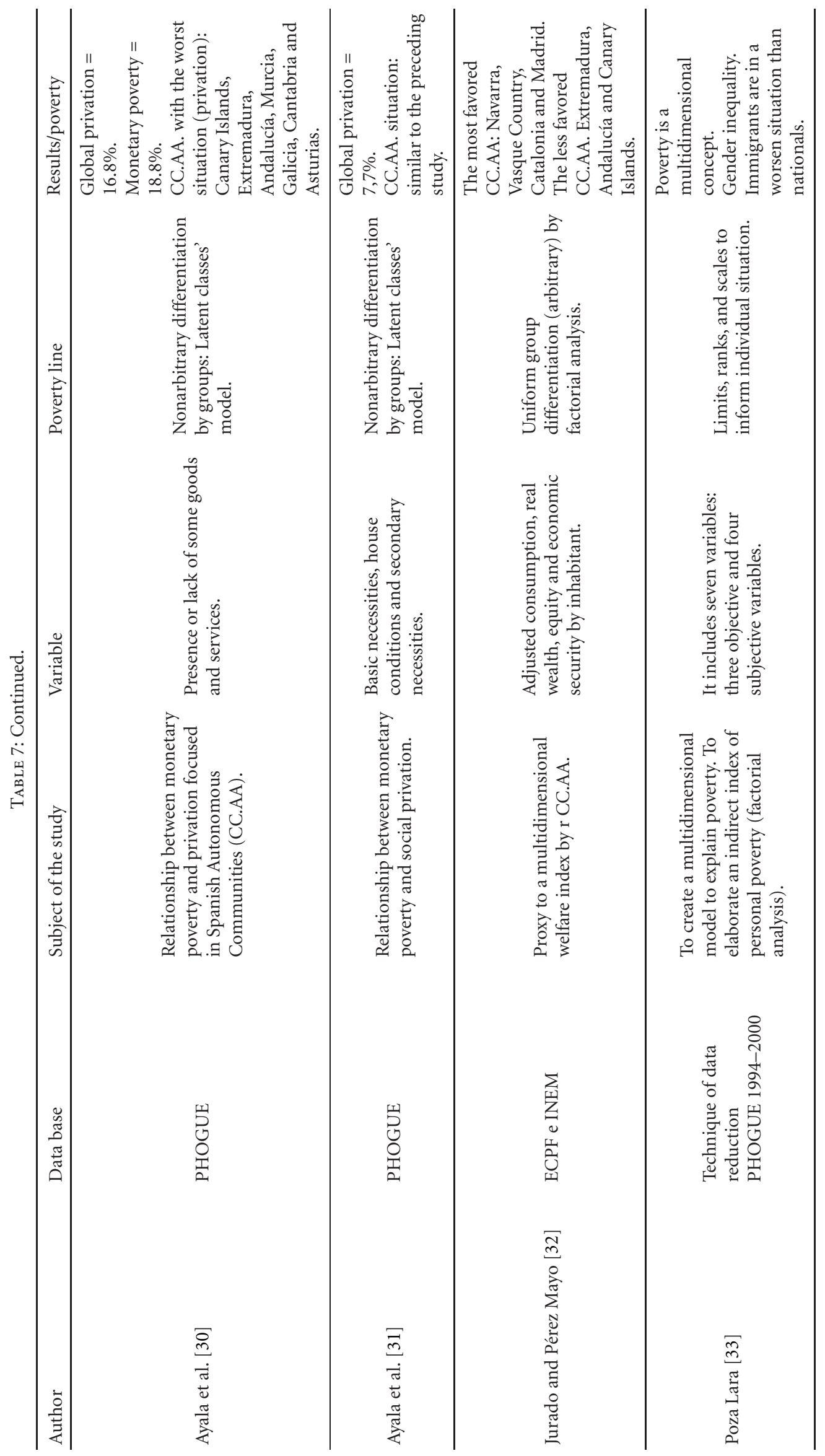




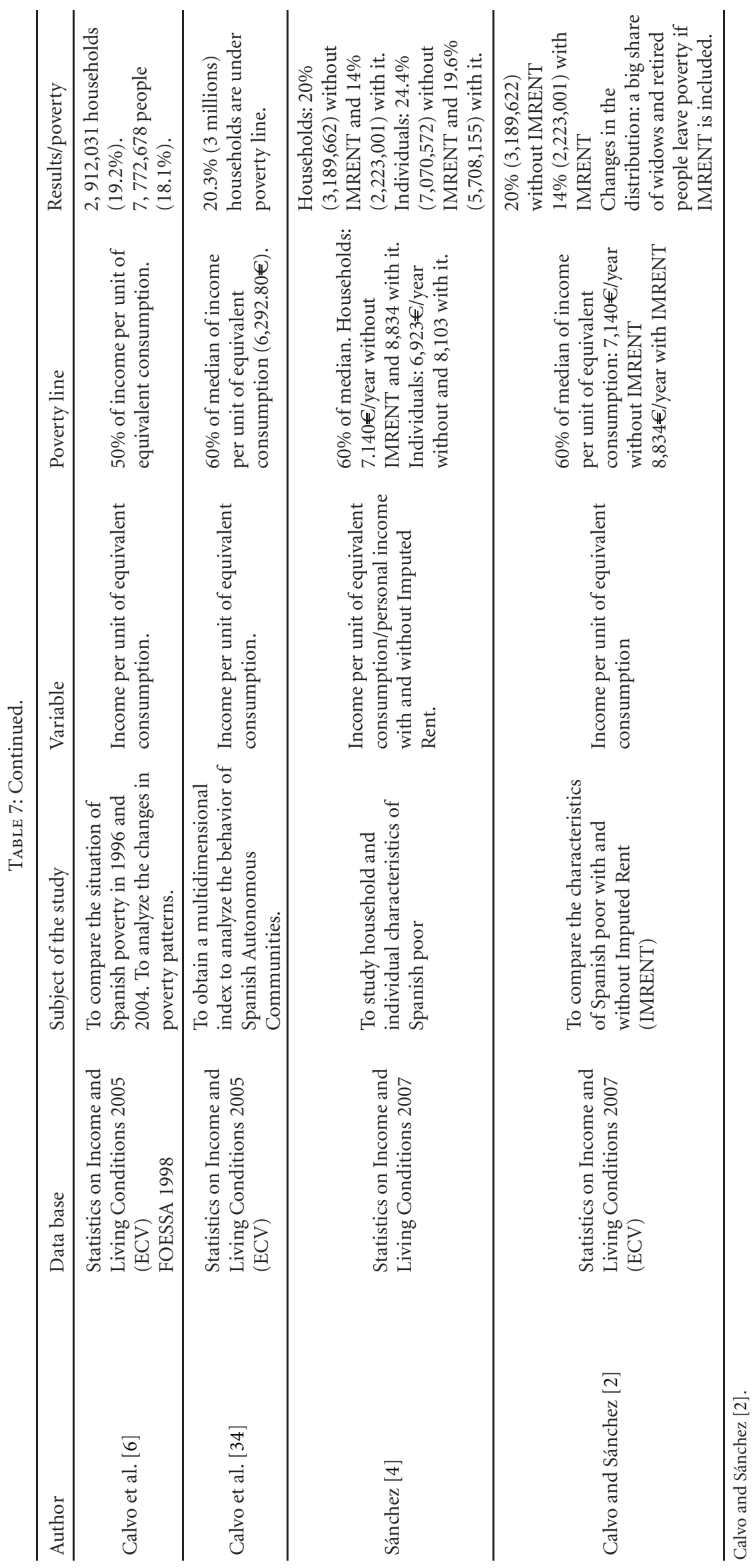


orientation must, however, be cognizant of changes in the Spanish property market and the ability of retirees to monetarize those assets.

\section{Acknowledgment}

The authors are very grateful to the comments of an anonymous referee.

\section{References}

[1] C. C. B. Plan, Situación de Pobreza y Desvalimiento Social, capter 3, Cáritas Española, Editorial Suramérica, Madrid, Spain, 1965.

[2] J. Calvo and C. Sánchez, "Changes in the characteristics of Spanish poor households: the case of Imputed Rent," in Proceedings of the Communication presented to the 50th ERSA Congress, Jönköping, Sweden, August 2010.

[3] INE, "Encuesta de Condiciones de Vida. Metodología general," 2007, http://www.ine.es/daco/daco42/condivi/ecv_ metodo.pdf.

[4] C. Sánchez, Distribución de la renta en España: análisis de la pobreza, Ph.D. thesis, UNED, Madrid, Spain, 2010.

[5] A. K. Sen, "Poverty: an ordinal approach to measurement," Econometrica, vol. 44, no. 2, pp. 219-231, 1976.

[6] J. Calvo, J. Martínez, and C. Sánchez, Evaluación de las condiciones de vida de la población pobre en España. Un análisis comparativo del Informe FOESSA 1998 y la ECV 2005, Ministry of Labor and Immigration. State Secretary for Social Security. FIPROS Project, 2008.

[7] FOESSA, Informes sociológicos sobre la realidad social de España, Editorial Euramérica, Madrid, Spain, 1976.

[8] INE, La Renta Nacional y su Distribución, Instituto Nacional de Estadística, Madrid, Spain, 1983.

[9] EDIS, "Pobreza y Marginación," Documentación social, no. 5657, 1984.

[10] M. de Trabajo, Pobreza e Inseguridad en España, 1985, Cited in J. Martínez Álvarez (2003) Economía de la Pobreza. UNED.

[11] J. Ruiz Castillo, La medición de la pobreza y la desigualdad en España. 1980-81, Estudios Económicos no. 42, Servicio de Estudios del Banco de España, Madrid, Spain, 1987.

[12] A. Bosch, C. Escribano, and I. Sánchez, "La desigualdad y la pobreza en España: 1973-1981," Papeles de Trabajo de la Fundación Ortega y Gasset 01/88, 02/88, 03/88, 1989.

[13] M. Ohiggins and S. Jenkins, "Poverty in the EC, estimates for 1975, 1980 and 1985," in Proceedings of the Analysing Poverty in the European Community. Policy Issues, research options and data sources, Papers presented at the seminar, R. Teekens and B. van Praag, Eds., Poverty Statistics in the European Community, Eurostat News, Special edition, 1989.

[14] ECB-Equipo De Economía Cuantitativa del Bienestar de La Universidad De Málaga, "Contexto económico de la pobreza en España," Cáritas, no. 288, supplement 144, Madrid, Spain, 1989.

[15] C. Escribano, "Evolución de la pobreza y la desigualdad en España 1973-1987,” Información Comercial Española, no. 686, pp. 81-108, 1990.

[16] Eurostat, "Poverty statistics base on microdata (Results for nine member states)," Report to CE Statistical Office elaborated by Erasmus University (Rotterdam) pov.50/92 EN, Luxemburgo, 1992.

[17] INE, "Estudio de los hogares menos favorecidos según la encuesta de presupuestos familiares 1990-1991," First results, Madrid, Spain, 1993.

[18] L. Ayala, R. Martínez, and J. Ruiz Huerta, "La distribución de la renta en España en los años ochenta: una perspective comparada," in Proceedings of the Conference in Actas del I Simposio sobre igualdad y distribución de la renta y la riqueza, vol. 2, pp. 101-136, Madrid, Spain, 1993.

[19] A. García Linaza and G. Martín Reyes, La Distribución Territorial de la Pobreza en España, chapter 2, V Informe FOESSA, Madrid, Spain, 1993.

[20] FOESSA, Informes Sociológicos, Editorial Euramérica, Madrid, Spain, 1994.

[21] J. Ruiz-Huerta and R. Mar $\neg$ tínez, 1994, La pobreza en España ¿qué nos dicen las encuestas de presupuestos familiares? La pobreza en España hoy, Documentación Social no. 96. Cáritas.

[22] P. (DIR.) Martín Guzmán, "Desigualdad y pobreza en España. Estudio basado en las Encuestas de Presupuestos Familiares de 1973-74, 1980-81 y 1990-91," INE y UAM, Madrid, Spain, 1996.

[23] FOESSA, Las condiciones de vida de la población pobre en España. Informe General, FOESSA, Madrid, Spain, 1998.

[24] C. Poza Lara, C. Evolución de la pobreza en España: un análisis descriptivo, 1996-2001, Mimeo. Cited in Poza Lara, C. (2007).

[25] J. Pérez Mayo, M. A. Fajardo, and M. Sánchez Rivero, "Cálculo de un indicador de privación mediante un modelo de clases latentes," in Proceedings of the Conference in 14th Reunion Nacional ASEPELT, Oviedo, Spain, June 2000.

[26] R. Mar $\neg$ tínez and J. Ruiz-Huerta, 2000, Income, multiple deprivation and poverty: an empirical analysis using Spanish data. Measures of poverty and social exclusión. Paper no. 5, Poland. International Association for Research in Income and Wealth .

[27] J. Oliver, X. Ramos, and J. L. Raymond, "Anatomía de la distribución de la renta en España, 1985-1996: la continuidad de la mejora," Papeles de Economía Española, vol. 88, pp. 67$88,2001$.

[28] M. Adiego Estrella and C. Moneo Ocaña, Pobreza y pobreza persistente en España. 1994-2000, Instituto Nacional de Estadística, Madrid, Spain, 2002.

[29] L. Ayala and C. Navarro, "Multidimensional indices of housing deprivation with application to Spain," Instituto de Estudios Fiscales Working Paper 12, pp. 1-31, 2004.

[30] L. Ayala, A. Jurado, and J. Pérez Mayo, Pobreza y privación: un análisis regional, Universidad de Extremadura, Instituto de Estudios Fiscales y Universidad Rey Juan Carlos (mimeo), 2006.

[31] L. Ayala, A. Jurado, and J. Pérez Mayo, "Pobreza monetaria y privación multidimensional: "qué explica el análisis territorial," Universidad de Extremadura, Insituto de Estudios Fiscales y Universidad Rey Juan Carlos, 2006, http://www .ual.es/congresos/docs/Distribucion/Distribucion\%204/Ayala \%20Jurado.pdf.

[32] A. Jurado and J. Pérez Mayo, "Aproximación a un índice de bienestar económico multidimensional para las CC.AA. españolas," Universidad de Extremadura, 2006, http://economiapublica.com/ponencias/3.11.pdf.

[33] C. Poza Lara, Pobreza multidimensional: el caso específico español a través del Panel de Hogares de la Unión Europea, Doctoral dissertation, Universidad Complutense de Madrid, Madrid, Spain, 2007.

[34] J. Calvo, J. Martínez, and C. Sánchez, "Poverty in Spain: a regional analysis," Studia Regionala, vol. 23, pp. 101-118, 2009. 


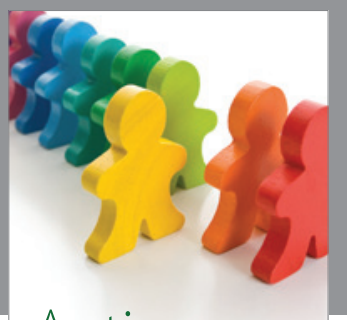

Autism

Research and Treatment
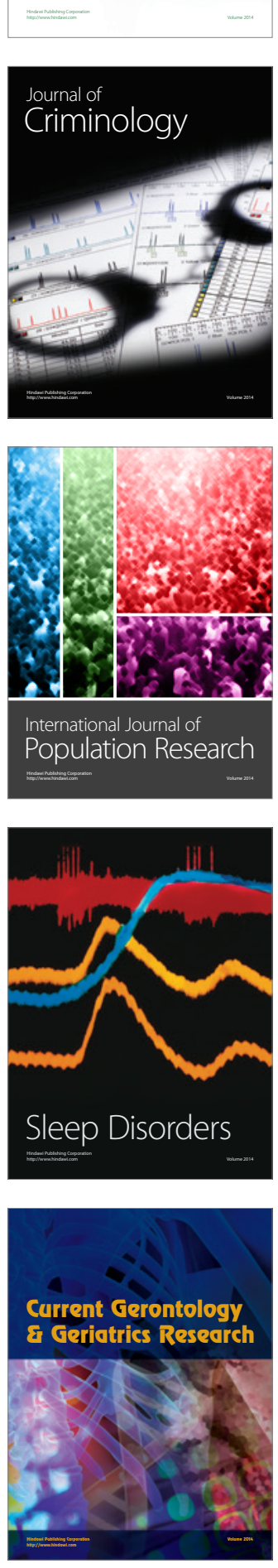
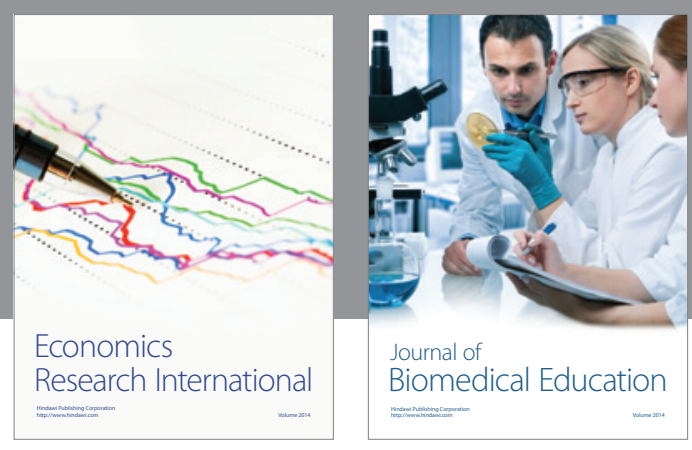

Journal of

Biomedical Education

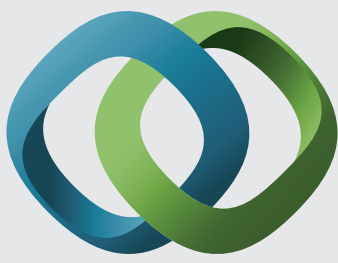

\section{Hindawi}

Submit your manuscripts at

http://www.hindawi.com
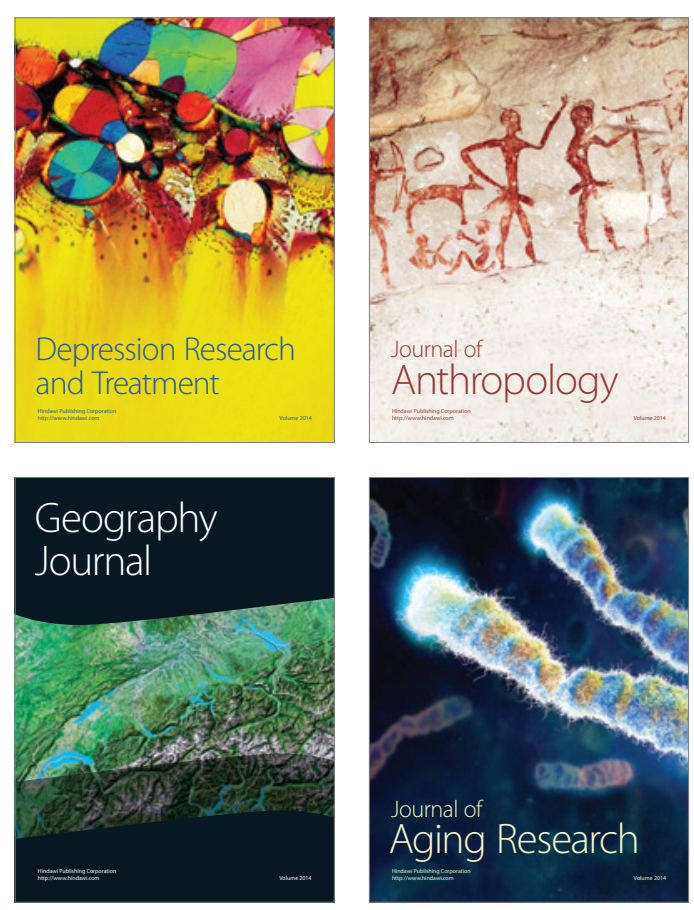

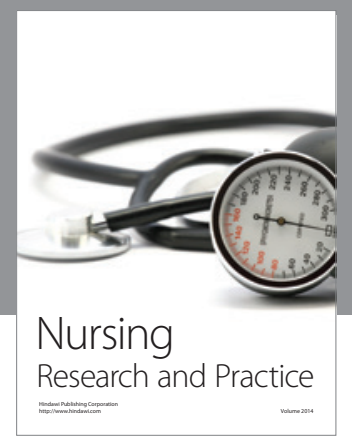

Nursing

Research and Practice

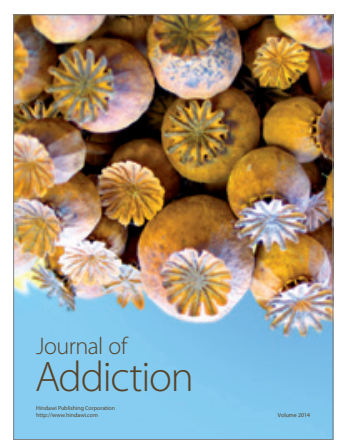

Child Development

Research

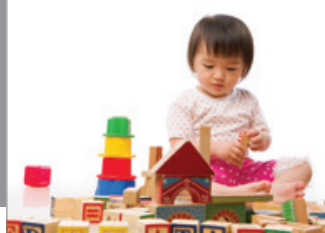

迥
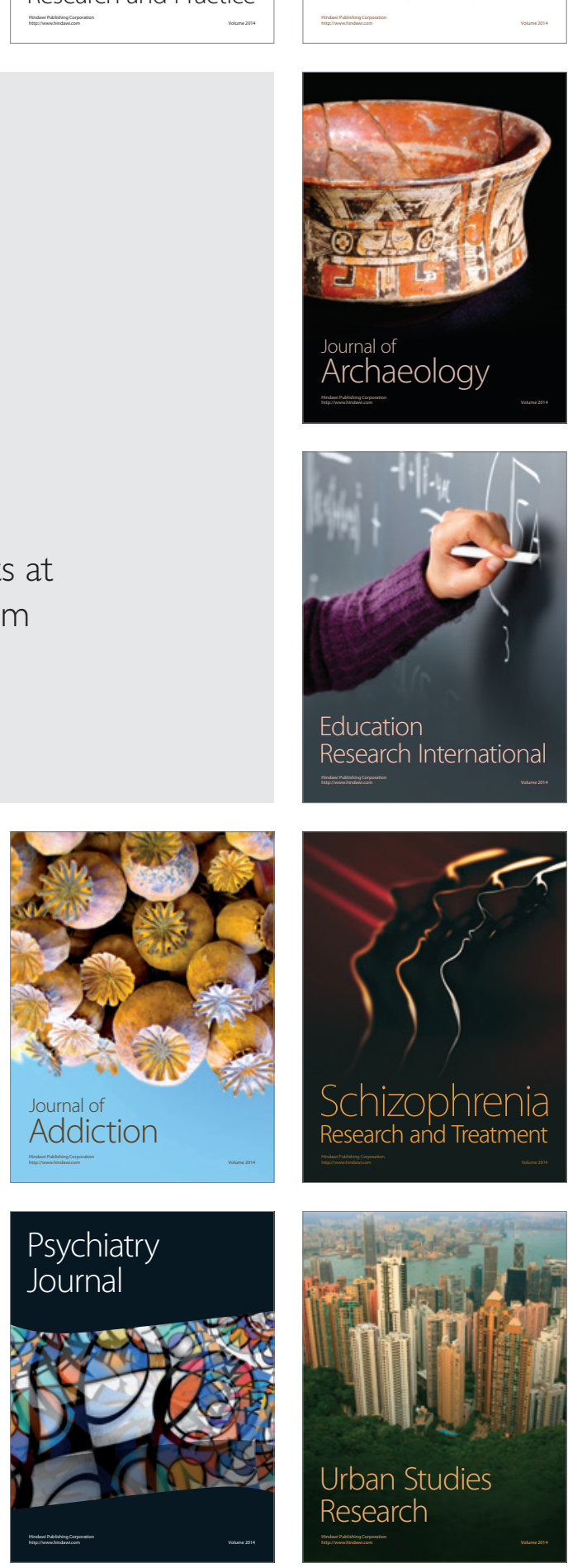